\title{
Spatial distribution of seeds and juveniles of Enterolobium glaziovii Bentham (Leguminosae, Mimosoideae) in the Atlantic forest, Brazil
}

\author{
Flavio Nunes Ramos ${ }^{1,3}$, Dalva M. Silva Matos ${ }^{2}$ and Flavio A.M. Santos ${ }^{1}$
}

Received: July 23, 2004. Accepted: February 16, 2005

\begin{abstract}
RESUMO - (Distribuição espacial de sementes e juvenis de Enterolobium glaziovii (Leguminosae, Mimosoidade) na mata Atlântica, Brasil). Os padrões de distribuição espacial de frutos e juvenis de Enterobium glaziovii Bentham foram avaliados em quatro parcelas circulares de $30 \mathrm{~m}$ de raio, centralizadas em uma árvore reprodutiva para determinar se o tamanho das copas das plantas parentais, topografia e cobertura de dossel influenciam esses padrões. Cada copa foi subdividida em oito triângulos irregulares e suas áreas calculadas. Cada parcela foi subdividida em quatro sub-parcelas, sendo duas nos terrenos inclinados para cima e duas nos inclinados para baixo. A cobertura de dossel de cada parcela foi estimada tanto na altura do peito $(1,30 \mathrm{~m})$, quanto na altura do chão, a cada três meses em 1998. O número de frutos e juvenis de E. glaziovii foi quantificado. Apesar de ter havido mais frutos debaixo da copa da arvore parental $\left(F_{1,12}=0.01 ; p=0,92\right)$, não houve diferenças no número de juvenis embaixo ou fora da copa da planta parental $\left(F_{1,12}=0,88 ; p=0,36\right)$. Houve correlação positiva entre a área das copas e o número de frutos e juvenis embaixo delas $(\mathrm{r}=0,62 ; \mathrm{df}=14 ; \mathrm{p}<0,05)$. A maioria dos frutos e juvenis foi encontrada nos terrenos inclinados para baixo. A cobertura de dossel foi menor na primavera, porém maior embaixo da copa das plantas reprodutivas (apenas na altura do peito). Esses resultados indicam que a copa das plantas parentais, topografia e cobertura de dossel influenciam o padrão de distribuição espacial e provavelmente também a dinâmica de sementes e juvenis de E. glaziovii.
\end{abstract}

Palavras-chave: chuva de sementes, influência do parental, tamanho da copa, topografia

ABSTRACT - (Spatial distribution of seeds and juveniles of Enterolobium glaziovii Bentham (Leguminosae, Mimosoideae) in the Atlantic forest, Brazil). The spatial distribution of fruits and juveniles of Enterolobium glaziovii Bentham were evaluated in four circular plots of $30 \mathrm{~m}$ radius, centered around reproductive individuals to determine whether the size of the parental crowns, topography, and canopy coverage influence these patterns. Each crown was subdivided into eight irregular triangles and the area of each was calculated. Each plot was subdivided into four sub-plots, two of them in an up-slope direction, and the other two in a down-slope direction. The canopy coverage for each plot was estimated at breast height $(1.30 \mathrm{~m})$ and at ground level, every three months during 1998 . The numbers of fruits and juveniles of E. glaziovii were recorded. Although there were more fruit under the parental crown $\left(\mathrm{F}_{1,12}=0.01 ; \mathrm{p}=0.92\right)$, there was no difference in the number of juveniles under and beyond the reproductive trees $\left(F_{1,12}=0.88 ; p=0.36\right)$. There was a positive correlation between the areas of the crowns and the numbers of fruits and juveniles under them $(r=0.62 ; \mathrm{df}=14 ; \mathrm{p}<0.05)$. Most of the fruits and juveniles were found in the down-slope directions. The canopy coverage was lower in spring, but higher under parental crowns (only at breast height). These results indicate that the parental crown, topography and canopy coverage influenced the pattern of spatial distribution and probably also the dynamics of E. glaziovii seeds and juveniles.

Key words : conspecific influence, crown size, seed shadow, topography

\section{Introduction}

The potential spatial distribution of plants within a population is determined by the distribution of seeds during dispersal (Clark \& Clark 1984). Seed dispersal is the last step in the reproductive cycle of plants, but also the starting point in the process of population renewal and recruitment (Herrera et al. 1994). The seed shadow of a tree species is a function of the efficiency of the dispersal agents, and of the tree's productivity (Janzen 1970), as well as soil conditions and microtopography (Loiselle et al. 1996). The post dispersal seed distribution is important because the growth and survival of plants depends on the locations reached by the seeds (Schupp 1988).

The probability of fruit or seeds falling far from the parent plants is dependent on their size or mass. Usually, a very large fraction of the total seeds fall

\footnotetext{
1 Universidade de Campinas, Instituto de Biologia, Departamento de Botânica, C. Postal 6109, CEP 13083-970, Campinas, SP, Brazil

2 Departamento de Ciências Naturais, UNIRIO, Av. Pasteur 458, Urca, CEP 22290-240, Rio de Janeiro, RJ, Brazil

3 Corresponding Author: fnramos@gmail.com
} 
close to the parental tree (Howe et al. 1985; Forget 1989), and the fraction is greatest for heavy seeds dispersed by gravity (Richards 1996). Seed dispersal by gravity or barochory is often characteristic of huge fruits with no other morphological features that enable them to be dispersed primarily by biotic (e.g., bats, birds, monkeys, elephants, rodents) or abiotic (e.g., wind, water) agents (Forget 1992b). According to Denslow (1980), the sizes and shapes of seed and perhaps seedling shadows of species that bear heavy fruit are expected to be related to the area of the parental crown and to topography. The spatial distribution of light is another important factor that may determine the seedling shadow (Smith et al. 1992).

The aim of this study was to describe the spatial distribution of E. glaziovii fruits and juveniles in order to answer the following questions: Do the sizes of parental crowns influence the spatial distributions of fruits and juveniles? Does topography influence the spatial distribution of fruit and juveniles of E. glaziovii? Does canopy coverage influence the spatial distribution of its juveniles?

\section{Material and methods}

Study area - The study was carried out in Biological Reserve of Poço das Antas (BIORE) (22 ${ }^{\circ} 29^{\prime}$ $22^{\circ} 36^{\prime} \mathrm{S}, 42^{\circ} 13^{\prime}-42^{\circ} 21^{\prime} \mathrm{W}$ ) and in the Parque Nacional da Tijuca, near the Rio de Janeiro Botanical Garden (RJBG) $\left(22^{\circ} 58^{\prime} \mathrm{S}, 43^{\circ} 13^{\prime} \mathrm{W}\right)$ in Rio de Janeiro State, Brazil. Four circular plots with $30 \mathrm{~m}$ of radius each centered $\left(2827.35 \mathrm{~m}^{2}\right.$ each plot) around a reproductive tree of Enterolobium glaziovii Bentahm. Three of the plots (B1, B2 and B3) were in BIORE and one of them (R1) was in RJBG. Both areas are classified as evergreen forest, or Ombrophilous Dense Forest (Velloso et al. 1991). The mean annual temperature at the BIORE is $27.6{ }^{\circ} \mathrm{C}$ in the summer and $21.3^{\circ} \mathrm{C}$ in the winter, with a mean annual rainfall of 2,092 mm (IBDF 1981b and data from the Golden Lion Tamarin Association collected from 1983 to 1998). In the RJBG, the mean annual temperature is $29^{\circ} \mathrm{C}$ in the summer and $22^{\circ} \mathrm{C}$ in the winter, with a mean annual rainfall of $1,075 \mathrm{~mm}$ (IBDF 1981a; Oliveira \& Lacerda 1988). All of the reproductive trees studied were isolated and very far from each other (no other E. glaziovii were found in these areas). BIORE and RJBG plots were separated by $126 \mathrm{~km}$ and the BIORE trees were $2.5-10 \mathrm{~km}$ apart. All of the plots were on slopes, where the inclination raged to $1.3^{\circ}$ from $60^{\circ}$ (Ramos 200).
Study species - Enterolobium (Leguminosae Mimosoideae) is a neotropical genus distributed from Central America (Mexico) to South America (Argentina), with the Amazon being the center of diversity (Mesquita 1990). The timber of this genus is used to make boats and packing cases. Enterolobium species are distinguished mainly by their fruit morphology, which is predominantly indehiscent. Among the 10 species of the genus, E. glaziovii has a restricted geographic distribution and is only found in three states in Brazil: Rio de Janeiro, Espirito Santo (SE Brazil) and Bahia (NE Brazil), being endemic to the Brazilian Coastal Atlantic forests (Mesquita 1990). This species, which occurs at a low frequency in forest sites (Lima, H.C. Botanical Garden of Rio de Janeiro, Brazil, pers. comm.), is a deciduous canopy tree with reproductive individuals ranging from $8-30 \mathrm{~m}$ in height (Mesquita 1990). Fruiting occurs in May and June and the tree loses its leaves in May, June and July. The contorted black woody fruits are large $(8-10 \mathrm{~cm} \times 4-5 \mathrm{~cm})$ and heavy $(14.6 \pm 6.4 \mathrm{~g})$ (Mesquita 1990) and contain 1-14 seeds, (mean of 9 seeds) (F.N. Ramos \& A.C.S. Andrade, data not published). No predation on seeds inside fallen fruits was observed in this study (F.N. Ramos \& A.C.S. Andrade, data not published).

Distribution of fruit and juveniles - The number of E. glaziovii juveniles was monitored in the circular plots from 1996 to 1999, and the number of fruit in each circular plot was sampled using four $30 \mathrm{~m}$ long wedges of $5^{\circ}$, extending in each of the four cardinal compass directions away from the central reproductive tree. The distance of all fruits from the parental tree was recorded in 1998 and 1999, as soon as the fruit fell. All E. glaziovii juveniles were marked.

Crown size - To assess the influence of the size and asymmetry of parental crowns on the spatial distribution of fruit and juveniles, each crown was divided into eight irregular triangles and the area $\left(\mathrm{m}^{2}\right)$ of each triangle was calculated by trigonometric relations. The distance from the bole to the crown edges of the individual was measured constructing a system of four wedges of $90^{\circ}$ in each of the four cardinal compass directions. The crown asymmetry was obtained by dividing the crown in halves, considering the maximum value among the possible pairs. The maximum value was calculated by dividing the largest of these two halves by the total area $\left(\mathrm{A}_{\max } / \mathrm{A}_{\text {total }}\right)$. This value varied between 0.5 (symmetry) and 1.0 ("complete" asymmetry) (Young $\&$ Perkocha 1994). The number of fruits and juveniles 
of E. glaziovii was determined under and beyond the crown and under each of the four crown triangles.

Topography - To assess the influence of topography on the spatial distribution of the fruits and juveniles of E. glaziovii, each plot, which was on a slope, was partitioned into two sub-plots in an up-slope direction (areas above the individual) and two sub-plots in a down-slope direction (areas below individual). The number of fruits and juveniles of E. glaziovii in each sub-plot was recorded.

Canopy coverage - Canopy coverage values were estimated at $1.30 \mathrm{~m}$ (breast height) and at ground height using a spherical concave densiometer. Samples were taken every $5 \mathrm{~m}$, from the central E. glaziovii to the boundary of each plot, along eight transects in the compass directions. The canopy coverage values were estimated every three months (at the beginning of each season) during 1998. Thus, for each season, canopy coverage values were recorded from 48 points at each height in each plot.

Statistical analysis - All data expressed as proportions were arcsine transformed before analysis to improve the homocedasticity and normality of the distributions, and were back-transformed in the tables and figures (Zar 1996). Differences in the proportions of fruits and juveniles of E. glaziovii between under and beyond the parental tree crowns and among years, and also between up and down - slope sites and among years were tested by two-way ANOVA. The canopy coverage between under and beyond the parental tree crowns and among seasons, and between up and down - slope and among seasons, were also compared by two-way ANOVA.

The Pearson correlation coefficient was used to examine the relationship between the area of each parental crown triangle and the mean proportion of fruit (among years) and also between the area of each parental crown triangles and the mean proportion of juveniles (among years) under it. This correlation coefficient was also used to assess the relationship between the median distance of the fruit from the parental tree and the size of the radii of the parental crown. The crown triangle areas were square root transformated before the correlation test.

\section{Results}

Crown size - The crown radii of the trees ranged from $5.1 \mathrm{~m}$ to $12.4 \mathrm{~m}$ and the crown areas ranged from 163.1 to $541.2 \mathrm{~m}^{2}$. All trees had asymmetric crowns
(0.67 to 0.94$)$ that were offset in the down-slope direction. The crown triangles that had greater areas also had a greater number of fruit $(\mathrm{r}=0.62$; $\mathrm{df}=14$; $\mathrm{p}<0.05)$ and juveniles $(\mathrm{r}=0.51$; $\mathrm{df}=14 ; \mathrm{p}<0.05)$ under them. However, there was no correlation between the radii of the parental crowns and the median distance of fruit from the parental bole $(\mathrm{r}=0.40 ; \mathrm{df}=6$; $\mathrm{p}>0.05)$ in sub-plots in the down-slope direction. In other words, greater crown radii did not represent an increase in the median distance of the fruit, from the bole to down-slope directions.

Distribution of fruit and juveniles - Seeds were only found inside the fruit. Although there were more fruit $\left(\mathrm{F}_{1,12}=52.5 ; \mathrm{p}=0.001\right)$ under the parental crown than beyond (Fig. 1) in both years $\left(F_{1,12}=0.01 ; p=0.92\right)$, there were no significant differences in the numbers of juveniles under and beyond the crowns $\left(\mathrm{F}_{1,12}=0.88\right.$; $\mathrm{p}=0.36)$ or among the years $\left(\mathrm{F}_{3,12}=0.01 ; \mathrm{p}=0.99\right)$ (Fig. 2). However, there were significantly more fruits $\left(\mathrm{F}_{1,12}=26.2 ; \mathrm{p}=0.001\right)$ (Fig. 1) and more juveniles $\left(\mathrm{F}_{1,12}=49.3 ; \mathrm{p}=0.001\right)$ in the down-slope direction than up-slope (Fig. 2), in both years $\left(\mathrm{F}_{1,12}=0.01\right.$; $\mathrm{p}=0.92$ and $\mathrm{F}_{3,12}=0.01 ; \mathrm{p}=0.99$, respectively).

Canopy coverage - The canopy coverage at the two heights was different. There was greater canopy coverage (CC) at $1.30 \mathrm{~m}$ under the parental crowns than beyond it $\left(\mathrm{F}_{1,12}=37.2 ; \mathrm{p}=0.001\right)$ and in the upslope direction compared to the down-slope $\left(\mathrm{F}_{1,12}=6.6 ; \mathrm{p}=0.011\right)$. Additionally, $\mathrm{CC}$ was lower in Spring, than the other seasons $\left(\mathrm{F}_{1,12}=3.4 ; \mathrm{p}=0.019\right.$ and $\mathrm{F}_{1,12}=3.2 ; \mathrm{p}=0.024$, respectively) (Fig. 3). In contrast, there were no significant differences in $\mathrm{CC}$ at ground height under or beyond the parental crowns

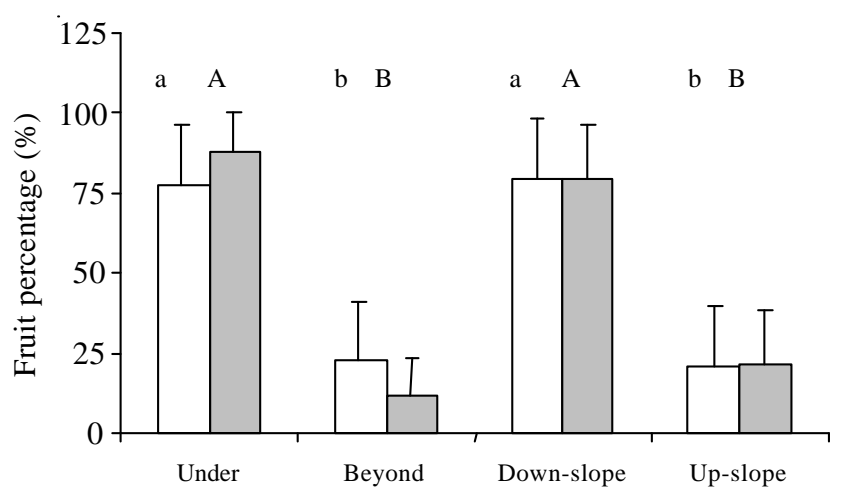

Figure 1. Percentage (mean \pm SD) of fruit of Enterolobium glaziovii Bentham under and beyond the central reproductive tree crown and in up- and down-slope directions in 1998 and 1999. The data were back transformed from the arcsine values. There were more fruit $\left(\mathrm{F}_{1,12}=52.5 ; \mathrm{p}=0.001\right)$ under the parental crown than beyond and in the down-slope direction than up-slope $\left(\mathrm{F}_{1,12}=\right.$ 26.2; $\mathrm{p}=0.001$ ) in both years. $\square=1998 ; \square=1999$. 


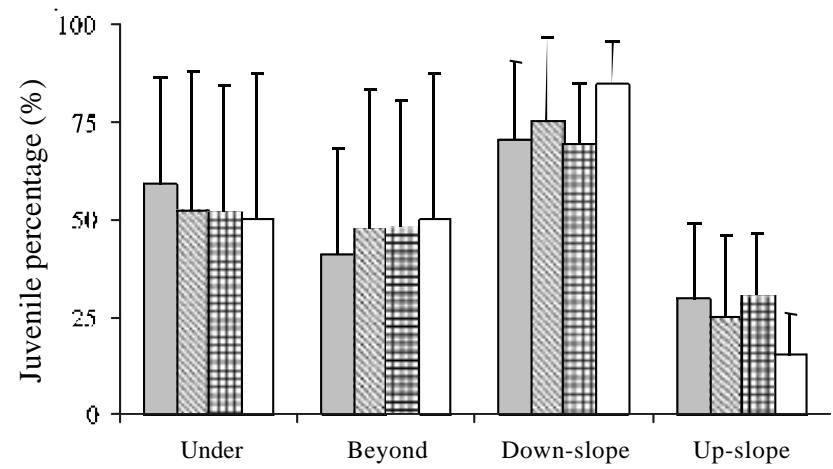

Figure 2. Percentage (mean $\pm \mathrm{SD}$ ) of juveniles of Enterolobium glaziovii Bentham under and beyond the central reproductive trees crowns and in up- and down-slope directions from 1996 to 1999. The data were back transformed from the arcsine values. There were no significant differences in the numbers of juveniles under and beyond the crowns $\left(\mathrm{F}_{1,12}=0.88 ; \mathrm{p}=0.36\right)$, but there were significantly more juveniles $\left(\mathrm{F}_{1,12}=49.3 ; \mathrm{p}=0.001\right)$ in the down-slope direction than up-slope in all years. $\quad=1996$; $\square=1997 ;$ 回 = 1998; $\square=1999$.

$\left(\mathrm{F}_{1,12}=0.29 ; \mathrm{p}=0.59\right)$ or in the up- or down-slope direction $\left(\mathrm{F}_{1,12}=0.26 ; \mathrm{p}=0.61\right)$, although $\mathrm{CC}$ was lower in Spring than the other seasons $\left(\mathrm{F}_{1,12}=6.5\right.$; $\mathrm{p}=0.001$ and $\mathrm{F}_{3,12}=6.8 ; \mathrm{p}=0.001$, respectively) (Fig. 4). All of the E. glaziovii juveniles were found under a canopy coverage of $>80 \%$, with most of them under a CC > 90\% (Tab. 1), however most of the CC values $(82.4 \%)$ were above $80 \%$.

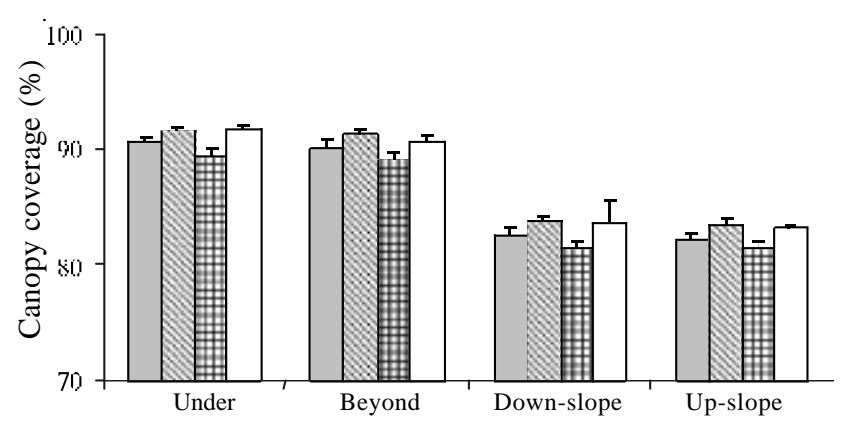

Figure 4. Percentage (mean \pm SE) of canopy coverage (CC) of Enterolobium glaziovii Bentham at ground height under and beyond the central reproductive trees crowns and in up- and down-slope directions in each season. The data were back transformed from the arcsine values. The only differences is that $\mathrm{CC}$ was lower in Spring than the other seasons $\left(\mathrm{F}_{1,12}=6.5\right.$; $\mathrm{p}=0.001$. $\square$ = Spring; $\square=$ Summer; 回 = Autumn; $\square=$ Winter.

\section{Discussion}

Juveniles of barochoric species generally grow near the parental trees, in a low light intensity environment (Forget 1992a). Studies of seed rain and seedling survivorship have shown that early seedling

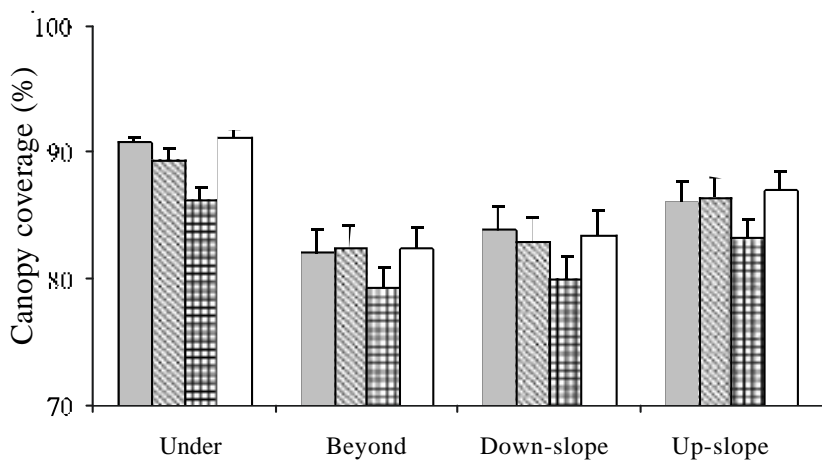

Figure 3. Percentage (mean \pm SE) of canopy coverage (CC, \%) of Enterolobium glaziovii Bentham at breast height under and beyond the central reproductive trees crowns and in up- and down-slope directions in each season. The data were back transformed from the arcsine values. There was greater canopy coverage under the parental crowns than beyond it $\left(\mathrm{F}_{1,12}=37.2 ; \mathrm{p}=0.001\right)$ and in the up-slope direction compared to the down-slope $\left(\mathrm{F}_{1,12}=6.6 ; \mathrm{p}=\right.$ 0.011). $\mathrm{CC}$ was lower in Spring, than the other seasons $\left(\mathrm{F}_{1,12}=3.4\right.$; $\mathrm{p}=0.019)$. $\square=$ Spring; $\square=$ Summer; $\mathbb{⿴ 囗 十}=$ Autumn; $\square=$ Winter.

recruitment may be spatially correlated with the seed rain, although this relationship may disappear as the seedlings age and become saplings (Herrera et al. 1994). High canopy coverage values ( $>80 \%$ ) could limit the range of plant species that are able to germinate, establish and growth around E. glaziovii adults. The results show the recently dispersed seeds of E. glaziovii, which its germination are not influenced by light (Ramos \& Santos, unpubl. data), are not exposed to light, because up to $1.3 \mathrm{~m}$ of height there was no difference in $\mathrm{CC}$ between under and beyond the central reproductive tree crown and between upand down-slope directions. E. glaziovii seeds are dispersed on the ground and germinated differently in time due to its differential dormancy. It seems the seedlings recruit and grow without much light influence until they achieve about $1.30 \mathrm{~m}$ of height, when the light begins influenced it. The juveniles beyond the central reproductive tree crown and in down-slope directions are under greater luminosity e consequently have greater chances of growth and establishment.

Table 1. Percentage of Enterolobium glaziovii Bentham offspring and the percentage of canopy coverage (CC) values measured sampled on each canopy coverage class (\%) in 1998.

\begin{tabular}{ccc}
\hline CC classes & CC measured & Offspring $(\%)$ \\
\hline $100-90$ & 48.2 & 82.4 \\
$80-90$ & 34.2 & 17.6 \\
$0-80$ & 17.6 & 0.0 \\
\hline
\end{tabular}


Ramos \& Santos (unpubl. data) show the juveniles greater than $50 \mathrm{~cm}$ of height grew more than the smaller ones. Additionally, in the spring or in the dry season, when the deciduous trees lost its leaves and consequently the light in the understory increase, may be the time when E. glaziovii juveniles have most of their height increment. However, in order to verify it, a study of the growth of each E. glaziovii juvenile during each season of the year would be necessary.

There was spatial and temporal variation in canopy coverage (CC). CC was lower in the Spring than in the other seasons, and there were differences between $\mathrm{CC}$ at breast height and at ground height. Although $\mathrm{CC}$ at ground height was homogeneous in the plots, $\mathrm{CC}$ at breast height was greater under the parental crown and in the up-slope direction. Most of the CC values were high $(>80 \%)$, since there were few small gaps in the plots. The difference between CC at breast height and at ground height also indicated that the light intensity reaching small plants and early seedlings was less than that reaching saplings or shrubs $\geq 1.5 \mathrm{~m}$ tall. The availability of light is probably a very important factor in the spatial distribution of juveniles, influencing their survival chances. The seasonal deciduousness of E. glaziovii adults generated fluctuations in the CC of the plots. E. glaziovii was probably, and the most important deciduous tree species in the plots since its crown covered about $1 / 3$ of each plot area.

Clumps of fruit under parental plants, such as observed here for E. glaziovii, have been found for many other plant species, especially those with heavy fruit (Forget 1989; 1992b; Herrera et al. 1994; Negi et al. 1996), such as Eperua grandiflora (Aublet) Benth. in French Guiana, in which most of the fruit occurs under the parental crown (Forget 1992a). Laman (1996) found that more than $50 \%$ of the fruits of two Ficus species (which bear small fruit), in a Bornean rain forest, fell under their own crown. The shape and size of the adult crown may influence the seed distribution on the ground (Ramirez \& Arroyo 1987). E. glaziovii trees with greater crown areas had more fruits and juveniles under them, in contrast to Copaifera publiflora Benth., for which trees with a smaller crown area presented greater seed density at the crown edge while trees with a larger crown area had greater seed density near the trunk (Ramirez \& Arroyo 1987).

The slope of the ground presents a strong influence on the fruit and seed shadow of barochoric species because fruit that falls to the ground can roll down the slope (Forget 1992a). Rain and trampling by animals can also contribute to the fruit being spread down-slope. The distribution of fruit and juveniles of E. glaziovii in the down-slope direction was similar to that found in a Bombacaceae species in Colombia (Denslow 1980), and Eperua grandiflora in French Guiana (Forget 1992a), both of which have large fruit. All of the plots studied were on slopes, although there was considerable variation in their declivities (F.N. Ramos, data not publushed). Since most of the fruits and juveniles occurred in the down-slope direction, there must be factors that help maintain this species in a sloping area and prevent it from descending to a flat region. According to Forget (1992a), secondary dispersers may help to distribute the fruit and seeds more homogeneously in the down- and up-slope directions. Secondary seed dispersal on the upper side of the slope could lead to gradual ridge colonization, and compensate for the slope effect that drives most of the seeds down the slope (Forget 1992b). However, the seed shadow in the plots studied probably has been little influenced by frugivorous animals in the last years, since there was abundant fruit on the ground that had not been touched for more than a year, in all of the plots. This could reflect the hunting activity of humans in the two reserves where the plots were located (Hydson Pinheiro, IBAMA, pers. com.), since hunting would reduce the number of fruit consumers. So, the future of this species could be threatened.

In conclusion, variation in crown size, topography and $\mathrm{CC}$ (spatial and temporal) together, seem to influence the distribution of E. glaziovii fruits and juveniles, creating an initial spatial distribution from fruits and influence a different distribution of juveniles. For example, seeds that fall far from parental trees have a greater chance of surviving (Ramos et al., unpubl. data). Therefore, the biotic and abiotic characteristics identified in this study may have contributed to our understanding of the dynamics of tree seedlings and juveniles.

\section{Acknowledgements}

The author thanks to Alexandre Fadigas de Souzas, Mariana Cassab Torres, Jose Filipe Caluca, Ludimila Siqueira, Rita Portela, Maria Isabel Braz, Leonardo Lima, Tiago Bosisio Quental, Jorge Nascimento, Jair Lage Siqueira Neto and Antônio Maximo Rosa for help in the field work, and the Golden Lion Tamarin Association for data on rainfall and temperature in the Biological Reserve of Poço das Antas. Alexandre Adalardo Oliveira, Fernando Roberto Martins, Gislene 
Maria Ganade and Marcelo Teixeira Nascimento provided stimulating comments on the manuscript. This work was supported by Fundação de Amparo à Pesquisa do Estado de São Paulo (FAPESP) - Grant $n^{\circ}$ 98/01264-0.

\section{Bibliographic references}

Clark, D.A. \& Clark, D.B. 1984. Spacing dynamics of a tropical rain forest tree: evaluation of the Janzen-Connell model. American Naturalist 124: 769-788.

Denslow, J.S. 1980. Notes on the seedling ecology of a largeseeded species of Bombacaceae. Biotropica 12: 220-222.

Forget, P.M. 1989. La regénération naturelle dúne espèce autochore de la forêt guyanaise: Eperua falcata Aublet (Caesalpinaceae). Biotropica 21: 115-125.

Forget, P.M. 1992a. Regeneration ecology of Eperua grandiflora (Caesalpinaceae), a large-seeded tree in French Guyana. Biotropica 24: 146-156.

Forget, P.M. 1992b. Seed removal and seed fate in Gustavia superba (Lecythidaceae). Biotropica 24: 408-414.

Herrera, C.M.; Jordano, P.; Lopez-Soria, L. \& Amat, J.A. 1994. Recruitment of a mast-fruiting, bird dispersed tree: bridging frugivore activity and seedling establishment. Ecological Monographs 64: 315-344.

Howe, H.F.; Schupp, E.W. \& Westley, L.C. 1985. Early consequences of seed dispersal for a neotropical tree (Virola surinamensis). Ecology 66: 781-791.

IBDF. 1981a. Plano de Manejo do Parque Nacional da Tijuca. Brasília, Ministério do Meio Ambiente.

IBDF. 1981b. Plano de Manejo da Reserva Biológica de Poço das Antas. Brasília, Ministério do Meio Ambiente.
Janzen, D.H. 1970. Herbivores and the number of tree species in tropical forest. American Naturalist 104: 501-528.

Laman, T.G. 1996. Ficus seed shadow in a Bornean rain forest. Oecologia 107: 347-355.

Loiselle, B.A.; Ribbens, E. \& Vargas O. 1996. Spatial and temporal variation of seed rain in a tropical lowland wet forest. Biotropica 28: 82-95.

Negi, A.S.; Negi, G.C.S. \& Singh, S.P. 1996. Establishment and growth of Quercus floribunda seedlings after a mast year. Journal of Vegetation Science 7: 559-564.

Oliveira, R.R. \& Lacerda, L.D. 1988. Contaminação por chumbo na serrapilheira do Parque Nacional da Tijuca RJ. Acta Botânica Brasílica 1: 165-169.

Ramirez, N. \& Arroyo, M.K. 1987. Variación espacial y temporal en la depredación de semillas de Copaifera pubiflora (Leguminosae:Caesalpinoideae) en Venezuela. Biotropica 19: 32-39.

Richards, P.W. 1996. The tropical rain forest. Cambridge, Cambridge University Press.

Schupp, E.W. 1988. Seed and early seedling predation in the forest understory and in treefall gaps. Ecology 70: 1603-1609.

Smith, A.P.; Hogan, K.P. \& Idol, J.R. 1992. Spatial and temporal patterns of light and canopy structure in a lowland tropical moist forest. Biotropica 24: 503-511.

Velloso, H.P.; Rangel Filho, A.L.R. \& Lima, J.C.A. 1991. Classificação da vegetação brasileira, adaptada a um sistema universal. Brasília, Fundação Instituto Brasileiro de Geografia e Estatística - IBGE.

Young, T.P. \& Perkocha, V. 1994. Treefalls, crown asymmetry, and buttresses. Journal of Ecology 82: 319-324.

Zar, J.H. 1996. Biostatistical analysis. New Jersey, Prentice Hall. 